\section{NOVA TELLVS}

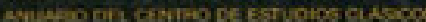

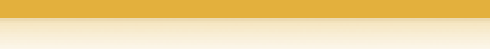

Álvarez Salas, Omar

Alma, cosmos e intelecto en el pensamiento presocrático: de Tales a Heráclito

Nova Tellus, vol. 26, núm. 1, 2008, pp. 19-54

Centro de Estudios Clásicos

Distrito Federal, México
Nova Tellus

ISSN: 0185-3058

novatelu@servidor.unam.mx

Centro de Estudios Clásicos

México

Disponible en: http://www.redalyc.org/articulo.oa?id=59115488001

- Cómo citar el artículo

- Número completo

- Más información del artículo

- Página de la revista en redalyc.org 


\title{
Alma, cosmos e intelecto en el pensamiento presocrático: de Tales a Heráclito
}

\author{
Omar Álvarez SALAS \\ Universidad Nacional Autónoma de México \\ omaralvar@hotmail.com
}

\begin{abstract}
RESUMEN: Este artículo rastrea el desarrollo, en manos de los pensadores presocráticos más antiguos, de la concepción de un alma universal que da origen y sostiene al cosmos en virtud de su función como principio inteligente creador del orden universal. Se mostrará en especial cómo dicha dimensión cósmica del alma presenta un paralelismo perfecto con el papel que las doctrinas escatológicas contemporáneas asignaron al alma individual del hombre, vista como portadora no sólo de la vida sino también de las funciones intelectivas. Asimismo, se destacará la posición de Heráclito como el filósofo presocrático del que poseemos las declaraciones más explícitas acerca de un monopolio tanto de las capacidades propiamente psíquicas como del pensamiento racional por parte del alma, la cual aún así aparece identificada en su sistema con el substrato de todo.
\end{abstract}

ABSTRACT: This paper follows the development of the conception of the cosmic soul among the earlier Presocratic thinkers: according to them, this particular function of the soul makes of it the source and support of the cosmos, insofar as it acts as an intelligent principle that brings about universal order. Especially, it will be showed how the cosmic dimension of soul exhibits a perfect parallelism to the role assigned to man's individual soul in contemporary eschatological doctrines: these viewed soul as bearer not just of life but also of every intellective function. Moreover, stress will be laid on Heraclitus' place as the Presocratic philosopher whose fragments contain the most explicit statements on soul's monopoly both of strictly psychic capacities and of rational thought, in spite of being also identified by him with the substratum of the whole world.

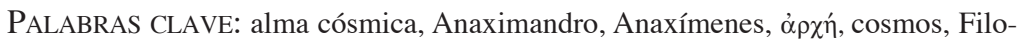

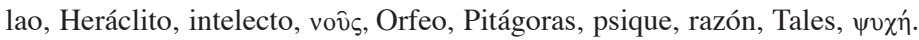

RECEPCIÓN: 10 de enero de 2008.

ACEPTACIÓN: 29 de mayo de 2008.

NOVA TELLVS, 26•1, 2008 


\title{
Alma, cosmos e intelecto en el pensamiento presocrático: de Tales a Heráclito
}

\author{
Omar Álvarez SALAS
}

Con base en la convicción de que el complejo mundo fenoménico que los rodeaba no podía estar sujeto a un azaroso e imprevisible caos en el que las cosas, sin sujetarse a ninguna regla aparente, sucederían por voluntad de uno o varios seres divinos, los pensadores presocráticos se esforzaron por descubrir la presencia en el universo de una organización u orden subyacente, que designaron consecuentemente con el término cosmos. En efecto, de acuerdo con la cosmovisión racionalista desarrollada por ellos, cada parte del mundo estaría rigurosamente insertada en el todo con arreglo a un plan inteligente y los sucesos naturales tendrían lugar siguiendo leyes precisas e ineludibles, además de siempre vigentes y de aplicación universal. En apego al diseño de un todo ordenado como el intuido por ellos, los primeros filósofos se esforzaron por consiguiente en reducir a unidad (o por lo menos a un conjunto muy limitado de 'elementos') el desconcertante abigarramiento del mundo visible, donde la multiplicidad de los entes vuelve prácticamente inabarcable el dominio de la experiencia sensible, dada la imposibilidad virtual de agotarlo por catalogación. Así pues, en los sistemas naturales teorizados sucesivamente por cada uno de los presocráticos se reconoció el papel de substrato original o principio (que se designa habi-

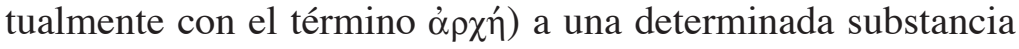
(o compuesto), a partir de la cual, a través de mecanismos

NOVA TELLVS, 26•1, 2008 
muy precisos y regulares, habrían surgido los demás seres en cumplimiento de una necesidad ineluctable, y a la cual todos éstos habrían de regresar en última instancia al cumplirse su ciclo natural de existencia.

"Todas las cosas tienen su principio y su fin en una sola" puede considerarse nada menos que el dogma fundamental de la ciencia física arcaica, cuya primera enunciación, según un conocido esquema de fabricación etiológica, se atribuyó a posteriori al mítico Museo, 'discípulo’ de Orfeo. Con todo, la propia doxografía antigua delata el carácter artificial de dicha atribución, pues a propósito del mismo principio de unidad original nos transmite formulaciones modeladas sobre el mismo patrón verbal, aunque con mención de un substrato específico, como por ejemplo el aire de Anaxímenes o el fuego de Heráclito. ${ }^{2}$ En cualquier caso, el testimonio más antiguo del principio de pensamiento que nos interesa aquí, conservado por cierto verbatim, corresponde a un fragmento de Jenófanes, que si bien oscila entre la admisión de una o dos $\alpha \rho \chi \alpha i^{\prime},{ }^{3}$ demuestra aun así su apego a dicho dogma cuando asigna de manera inequívoca a la tierra la función de fuente primera y destino final de todas las cosas, declaración que leemos en un hexámetro que reproducimos textualmente:

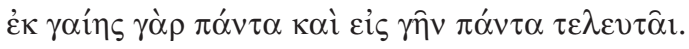

Todas las cosas [surgen] de la tierra y todas acaban en la tierra.

(Xen. 21 B 27 D.-K.)

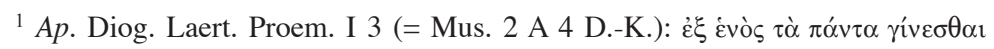

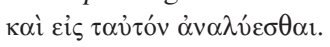

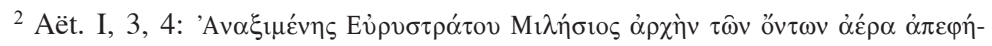

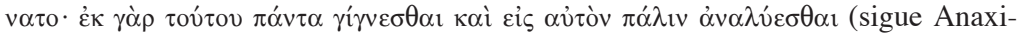
men. 13 B 2 D.-K.); para el fuego heracliteo como substrato material de todo léase

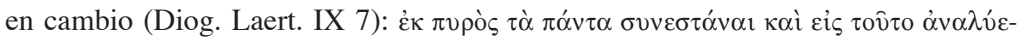
$\sigma \theta \alpha 1$.

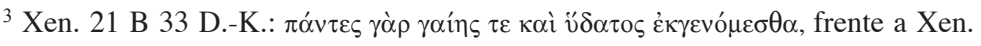
21 B 27 D.-K. (arriba, en el texto).
} 
Además, una formulación explícita y de valor testimonial indudable del principio universal del origen de todo en (y de su retorno a) un único substrato se lee en Heráclito de Éfeso, que busca con singular tesón revelar la unidad subyacente a la multiplicidad fenoménica, subrayando que en realidad "todo es uno". En efecto, una y otra vez en los fragmentos heracliteos que han llegado hasta nosotros asistimos a la reafirmación enfática de esa unidad última, que por cierto encontramos formulada de manera incontrovertible en este pasaje:

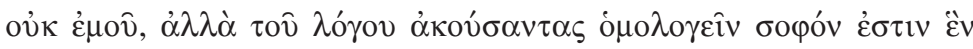

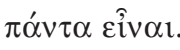

Prestando oído no a mi, sino al logos, es sabio reconocer que todas las cosas son Uno.

(Heraclit. 22 B 50 D.-K.)

unidad que el filósofo efesio identifica expresamente con el origen y destino de todas las cosas en este otro fragmento:

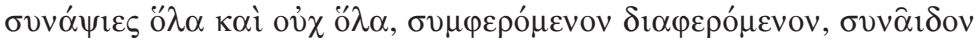

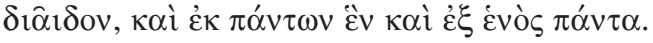

Conjunciones: compactos y no compactos, convergente divergente, consonante disonante, y de todos uno y de uno todos.

(Heraclit. 22 B 10 D.-K.)

Dicha intuición, sin embargo, que según vimos aparece de manera recurrente, con múltiples variaciones, en varios otros pensadores presocráticos, encuentra finalmente una expresión de notable claridad teórica y muy afortunada factura poética en el siguiente pasaje de Empédocles:

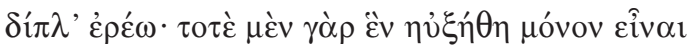

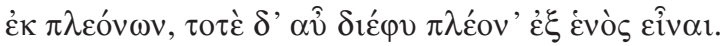

Diré un doble discurso: a veces muchas cosas se concretan en un solo ser, y otras veces, de ser uno, se dispersan para ser de nuevo muchas.

(Emp. 31 B 17 D.-K., vv. 1 s.) 
Observemos, sin embargo, en honor al debido rigor historiográfico, que este último pasaje es más precisamente un testimonio del tipo de alternativa desarrollada por los pluralistas, tras el perentorio desafío inmovilista lanzado por Parménides, para reconciliar la existencia de una multiplicidad fenoménica con el principio de unidad postulado por el filósofo de Elea. En efecto, Empédocles estuvo entre los pensadores que respondieron a la incisiva intervención del eleático asignando a un número determinado de substancias (cuatro en su sistema que se volvería después canónico $)^{4}$ el carácter de 'raíz', correspondientes a lo que Aristóteles llamaría a su vez 'elementos'. Asimismo, el propio filósofo de Agrigento postuló, para la interacción entre dichas substancias fundamentales, una alternancia cíclica entre el predominio del Amor, marcado por una unidad armónica o solidaridad total de los cuatro elementos bajo la forma del $\Sigma$ poîpos, y el imperio de la Contienda (o Discordia), donde, tras la disgregación de la esfera primigenia, se daba pábulo a un complejo y fortuito juego de combinación de los elementos, en variable número y proporción: de ahí 'nacerían' por agregación los múltiples seres de la realidad visible, los cuales habrían luego de disolverse de nuevo en sus elementos constitutivos, proceso al que en el lenguaje común se da el nombre de 'muerte'. 5

Ahora bien, con especial atención a la identificación por

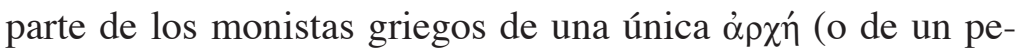
queño número de 'elementos'), es preciso recordar que dicha

\footnotetext{
${ }^{4}$ La elección que hizo Empédocles de sólo cuatro elementos primordiales, a

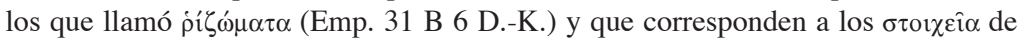
la terminología aristotélica posterior, estuvo apoyada en asociaciones consagradas en una antigua tradición poética que aparece registrada ya en Homero y Hesíodo - véase G. Cerri, "L'ideologia dei quattro elementi da Omero ai presocratici", AION, Sez. filol.-lett., 20, 1998; ya antes había rastreado la vertiente filosófica de dicha tradición C. H. Kahn, Anaximander and the Origins of Greek Cosmogony, New York, 1960 (pp. 133 ss.), también esbozada por W. K. C. Guthrie, A History of Greek Philosophy, Cambridge, 1962, vol. I, pp. 122 s. (y n. 1).

${ }^{5}$ Emp. 31 B 8; 9; 11 D.-K.
} 
búsqueda del elemento primigenio tiene paralelos mitológicos muy antiguos y arraigados en la tradición, que ya han sido bien identificados. ${ }^{6}$ Así pues, el 'agua' de Tales refleja por ejemplo una concepción ya presente en Homero y aún antes en varias mitologías orientales (mesopotamia, hebrea, etcétera), donde el caos primordial consistía de una masa indefinida de agua y donde el diluvio jugaba un papel importante en la (re-)generación de la vida. Dichos antecedentes mitológicos, con todo, no son obstáculo para negar que las cosmogonías presocráticas nos ponen de frente a una forma de especulación racional que seguramente debió de estar motivada también por algunas consideraciones de orden empírico. Aristóteles conjetura, en efecto, que Tales pudo haber buscado el origen de todas las cosas en el agua a raíz de la observación de que las plantas se nutren de la humedad y de que ésta se encuentra también en la comida y en el semen animal, aunque un hombre moderno quizá buscaría más bien la explicación en la capacidad del agua de transitar, a diferentes temperaturas, por los tres estados básicos de la materia (sólido, líquido y gaseoso). Como quiera que sea, está claro que los primeros filósofos griegos, pese a anticipar con notable exactitud en sus teorías físicas el principio de Lavoisier de la conservación de la materia (cosa que se resume en el adagio: nihil ex nihilo, nihil in nihilum), ${ }^{7}$

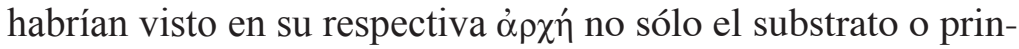
cipio material de todo lo existente, sino también la misma fuerza motriz de la transformación diversificadora, es decir aquello a lo que Aristóteles, en su examen crítico de las teorías presocráticas, se referiría como la causa del movimiento. ${ }^{8}$

\footnotetext{
${ }^{6}$ Para un panorama del trasfondo mítico sobre el que surgió la ciencia física griega, véase W. K. C. Guthrie, A History of Greek Philosophy, cit., vol. I, pp. 67 ss.

${ }^{7}$ Con todo, el testimonio griego más antiguo de este principio aparece en un contexto extrafilosófico, tomado quizá de un proverbio relativo a la esfera de la actuación humana, en un fragmento del poeta lesbio Alceo (fr. 320 L.-P.): кoí к'

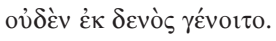

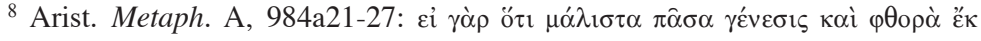

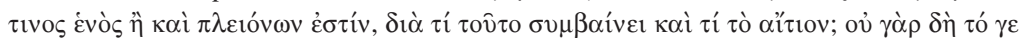


Desde el punto de vista de la mentalidad arcaica, en efecto, no tenía todavía sentido alguno la separación entre material e inmaterial (o espiritual), pues el incipiente pensamiento científico no había llegado aún a concebir la materia como substancia muerta o inerte, puesto que dicha noción habría conocido un desarrollo más bien paulatino, para consolidarse definitivamente sólo con el triunfo del dualismo cartesiano de materia y mente. ${ }^{9}$

Así pues, tratando de las doctrinas presocráticas más antiguas parece plenamente justificado hablar de hilozoísmo, es decir, de atribución de un carácter animado a la materia, como lo confirma sin lugar a dudas una serie de noticias sobre doctrinas del propio Tales: éste, según Aristóteles, habría afirmado que el imán tenía 'alma', usando aparentemente el término con el valor de "impulso motriz", aludiendo a su poder de desplazar el hierro a distancia; ${ }^{10}$ por otra parte, el mismo Estagirita, refiriéndose en otro pasaje a una doctrina antigua según la cual el alma estaría mezclada en el todo, reporta como de Tales la afirmación de que "todas las cosas están llenas de dioses". ${ }^{11}$ De estas declaraciones doxográficas se desprende con gran claridad la impresión de que el filósofo de Mileto al parecer habría expresado la capacidad de producir movimiento que reconocía en la materia, en completo acuerdo con su manera arcaica de pensar y expresarse, equiparándola a la posesión de una fuerza divina, es decir, concibiéndola ni más ni menos

نं

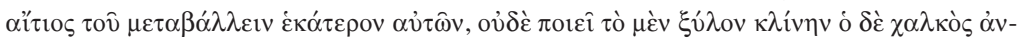

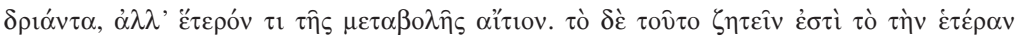

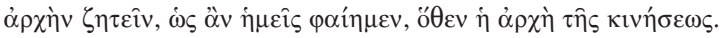

${ }^{9}$ Cfr. F. M. Cornford, Principium Sapientiae: the origins of Greek philosophical thought, Cambridge 1952, p. 179.

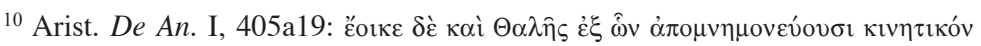

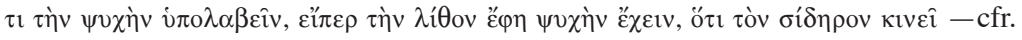
Aët. IV, 2, 1.

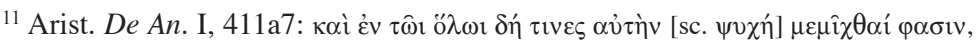

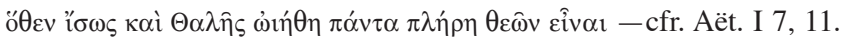


como un ser animado, como algo dotado de vida. En general, dicha cualidad se habría aplicado al substrato material o $\alpha \rho \chi \eta ́$, en la cual, dada su espontánea tendencia a transformarse en las diferentes substancias presentes en el mundo visible, se manifestaba con especial claridad el carácter 'animado', esto es, la

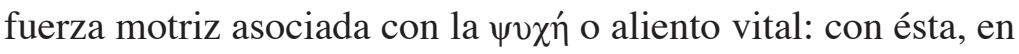
efecto, además de la fuerza de la vida, la ỏ $\chi$ ń tenía en común la naturaleza eterna, puesto que al disolverse las cosas del mundo sensible volvían al mismo substrato original del cual habían surgido, y esta condición de existencia eterna es algo que la mentalidad griega arcaica asociaba infaliblemente con lo divino, tò $\theta$ cîov. Por cierto, éste es justamente el calificativo que muchos de los presocráticos aplicaron a dicho substrato. Anaximandro, por ejemplo, parece haber llamado ‘divino' a tò

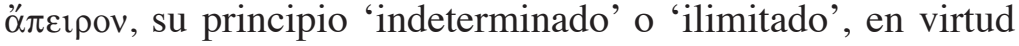
de su carácter inmortal e imperecedero, además de abarcar y gobernar todas las cosas, alcanzando en este punto un consenso

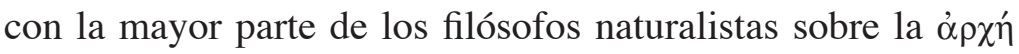
(cualquiera que fuera el nombre particular que cada uno le diera), según lo atestigua Aristóteles. ${ }^{12}$

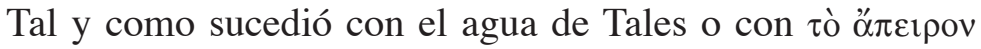
de Anaximandro, también las demás ỏ $\chi \alpha$ í postuladas por los primeros pensadores presocráticos fueron concebidas no sólo como substrato material, sino también como principio vital de todo el cosmos, por lo que se las describió constantemente como un ser eterno que contiene o abarca todas las cosas, un ser, por cierto, del que sale el impulso para el movimiento y, más precisamente, del que brota la vida que anima a cada uno

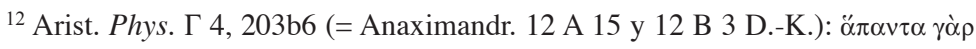

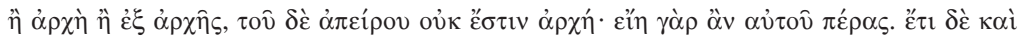

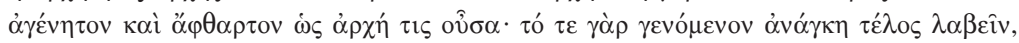

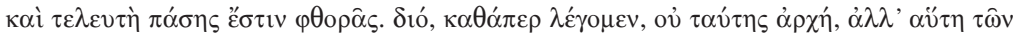

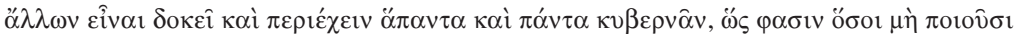

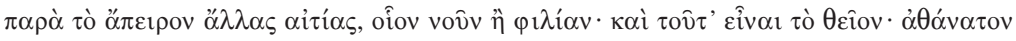

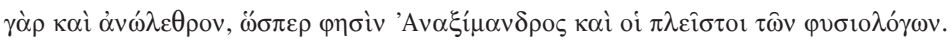


de los elementos del todo. Es así como Anaxímenes, el tercero de los monistas de Mileto, identificó la substancia fundamental en el aire, concebido como infinito y dotado de eterno movimiento, el cual, por estar sujeto a un proceso espontáneo (implícito en el propio substrato) de rarefacción o condensación alternadas, es decir, por sufrir alteraciones diferenciales de densidad, al volverse más rarefacta daba origen al fuego, $\mathrm{y}$, en cambio, al ir ganando densidad, se tornaba primero en viento (o sea, en aire) y en nube, a mayor densidad todavía pasaba a ser agua, luego tierra y rocas, a partir de lo cual surgía a continuación todo lo demás. ${ }^{13}$ Dicho aire del filósofo milesio, sin embargo, en tanto fuente original de todas las cosas, les proporcionaba no sólo la materia de que estaban constituidas, sino también la fuerza del movimiento que las generaba $\mathrm{y}$, en el caso de los seres vivientes, el principio mismo de la vida. Esta vez, la identificación por parte de Anaxímenes del aire como fuente vital de todo nos resulta aún más transparente que la de las anteriores $\alpha \rho \chi \alpha i$, pues continúa a todas luces la asociación tradicional de la respiración con el aliento vital

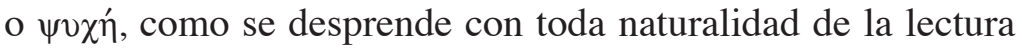
de un reporte doxográfico que tiene visos claros de transmitir una cita textual del milesio:

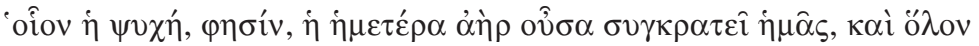

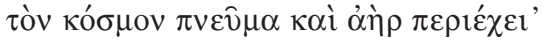

"Al igual que nuestra alma, dice [Anaxímenes], mantiene nuestra cohesión por su naturaleza aérea, así también es soplo y aire lo que abraza a todo el universo"

(Anaximen. 13 B 2 D.-K.) $)^{14}$

\footnotetext{
${ }^{13}$ Dicho reporte, que parece remontarse en última instancia a Teofrasto (Theophr. Phys. Opin. fr. 2 D. 476), se conserva en Simpl. Phys. 24, 26 (= Anaximen. 13 A 5 D.-K.).

${ }^{14}$ El fragmento es transmitido en Aët. I 3, 4 (para la parte del pasaje que lo precede véase arriba, n. 2).
} 
Ahora bien, la atribución de una composición aérea al alma en la doctrina de Anaxímenes se revela perfectamente congruente con una tradición muy antigua y ampliamente documentada desde el período arcaico. ${ }^{15}$ Según dicha concepción, que como veremos alcanzó una enorme difusión en la Antigüedad

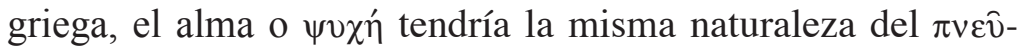
$\mu \alpha,{ }^{16}$ que es por cierto el término empleado para designar el aire dotado de movimiento, como lo sería justamente el alma vital. ${ }^{17}$ Dicha visión concuerda plenamente con la doctrina atribuida a Anaxímenes en la noticia arriba transcrita, donde se establece un paralelismo entre el 'microcosmos' del cuerpo humano, cuya cohesión es mantenida por el alma constituida de aire ( $\alpha \grave{\eta} \rho$ o $\sigma \alpha)$, y el 'macrocosmos' universal donde un

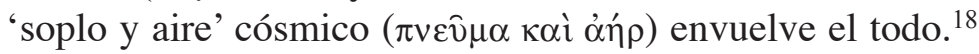

Aproximadamente en la misma época que Anaxímenes vivió Pitágoras, cuya doctrina de carácter no científico más conocida es la de la metempsícosis, según la cual el alma es inmortal y, al perecer el cuerpo en que se encuentra, puede pasar a otro

\footnotetext{
${ }^{15}$ Una noticia doxográfica atribuye incluso a Jenófanes el primado en la con-

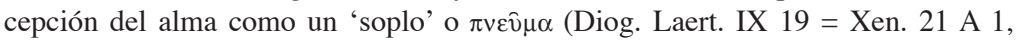

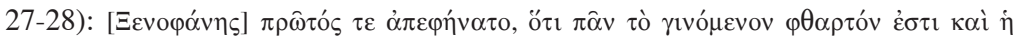

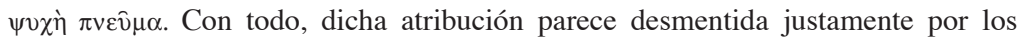
testimonios citados sobre la doctrina de Anaxímenes, además de por su amplia presencia en la visión escatológica de los griegos, como confirma su adopción por parte de órficos y pitagóricos (véase más adelante, en el texto).

${ }^{16}$ La difusión de la concepción aérea del alma entre los pensadores presocráticos debió de ser muy amplia, como parecen dar testimonio pasajes como el siguiente

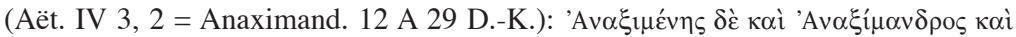

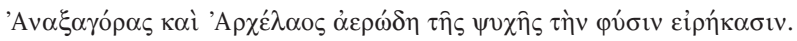

${ }^{17}$ Sobre esto véase E. Rohde, Psyche, Freiburg/Leipzig/Tübingen $1898^{2}$, vol. II, p. 258, n. 3, que señalaba una alusión a la doctrina pneumática del alma de

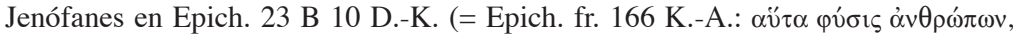

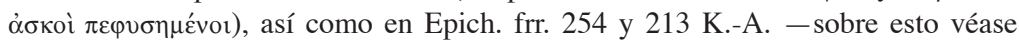
O. Álvarez, "Epicarmo e Senofane: tessere di una polemica", en Nova Tellvs, 25-2 [2007], pp. 85-136 (véanse las pp. 121 ss.).

${ }^{18}$ A propósito de la concepción 'pneumática' del alma se puede ver con provecho W. K. C. Guthrie, op. cit., vol. I, pp. 128 ss. (con pertinentes referencias bibliográficas en nota).
} 
cuerpo humano o animal, en virtud del estrecho lazo que une a todos los seres vivientes, que son considerados por ende como de la "misma familia". A nivel cósmico, dicha vinculación entre todas las formas de vida se explica justamente por la difusión del espíritu universal que impregna cada cosa conectando entre sí todas las formas de existencia, como se lee justamente en el siguiente testimonio:

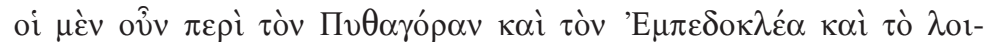

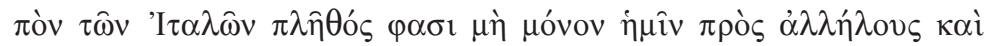

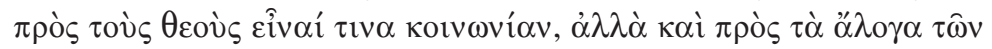

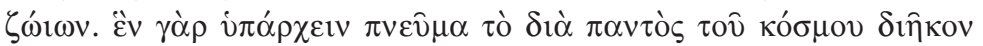

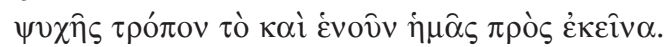

Los seguidores de Pitágoras y Empédocles, así como la restante multitud de los itálicos, afirman que hay un lazo común que nos vincula no sólo unos con otros y también con los dioses, sino además con los animales desprovistos de palabra. Dicen que existe un espíritu que se difunde por todo el universo a la manera de un alma, que también nos une con aquéllos.

(Sext. adv. math. IX 127)

Nuestra fuente nos informa, en efecto, que entre los griegos itálicos, a cuya cabeza pone a Pitágoras y Empédocles, tenía arraigo una concepción (en parte comparable a la de Anaxímenes) de que hay un alma cósmica, difundida por todo el universo, que enlaza a los hombres con las divinidades e incluso con los animales y las plantas, al grado de eliminar las fron-

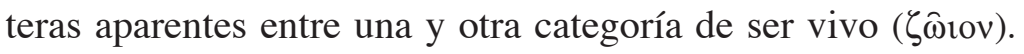
Así pues, resulta plenamente justificado identificar una etapa fundamental del proceso de consolidación de la concepción pneumática del alma en la doctrina de la metempsícosis al parecer desarrollada (o introducida) por Pitágoras y continuada por sus seguidores. ${ }^{19}$ Tenemos evidencias, por ejemplo, de

\footnotetext{
${ }^{19}$ Hay que observar aquí, sin embargo, que algunos testimonios, no precisamente autorizados, atribuyen a Ferécides, presunto maestro de Pitágoras (cfr. Diog. Laert. I 118 = Pherecid. 7 A 1 D.-K.), la prioridad como 'introductor' de la doctrina
} 
que el pitagorismo más antiguo, en el marco de la doctrina de la transmigración, desarrolló la concepción de que las almas, por ser de naturaleza pneumática, recorrían un trayecto aéreo en su paso de uno a otro cuerpo, y que dicho camino estaba por ende pletórico de ellas, las cuales lo usaban precisamente como vehículo, según veremos. Llama la atención de inmediato el interesante paralelismo que una semejante concepción presenta con la doctrina de Tales, a que ya nos hemos referido, sobre la presencia de 'dioses' en todas las cosas. Esto es, al menos, un hecho que puede establecerse a partir de un amplio reporte transmitido en la biografía de Pitágoras por Diógenes Laercio, sobre la autoridad del gran conocedor del pitagorismo Alejandro "Polyhistor" (activo polígrafo griego llevado como cautivo a Roma por Sila, que lo liberó en 82 a.C.), quien nos conserva una gran cantidad de información muy valiosa sobre contenidos doctrinales asociados con la fase más antigua de dicha secta. En el extracto de su escrito leemos el siguiente testimonio sobre la presencia en el pitagorismo antiguo de la concepción del alma cósmica y etérea, que aparece asociada con la idea del aire como lugar privilegiado de residencia de las almas:

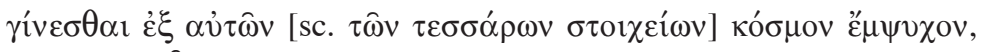

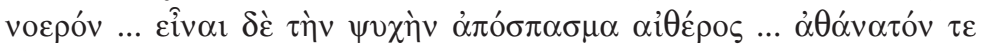

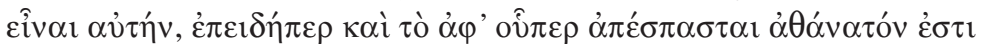

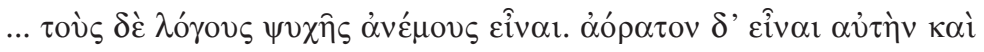

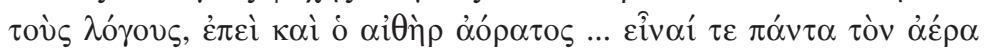
$\psi v \chi \hat{\omega} v \stackrel{\varepsilon}{\mu} \mu \pi \lambda \varepsilon \omega v \cdot \kappa \tau \lambda$.

De éstos [sc. los cuatro elementos] surge un universo dotado de alma, de intelecto ... El alma es un fragmento de éter ... Ésta es inmortal, puesto que efectivamente también aquello de lo que fue arrancada es inmortal. ... Las proporciones [sc. numéricas] del alma son vientos. Ésta es invisible, al igual que las proporciones,

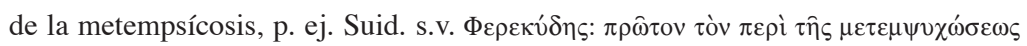

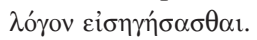


pues también el éter es invisible ... Todo el aire está lleno de almas; etc.

(Diog. Laert. VIII 24-33)

Al afirmar que, según la doctrina pitágorica referida, "todo el aire está lleno de almas", nos vemos inevitablemente remitidos a la doctrina de Tales que discutimos algunas páginas más arriba, según la cual "todas las cosas están llenas de dioses" y que encaja perfectamente en la visión hilozoísta de los presocráticos, a la que tenemos buenas razones de asociar también a Pitágoras y a su escuela. Más aún, basados en la autoridad de Aristóteles, podemos identificar incluso en el proceso de respiración del universo descrito por los pitagóricos, donde el

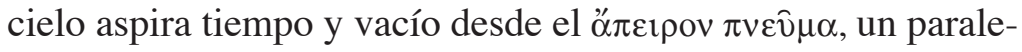
lo cósmico para la entrada del alma en los cuerpos individuales prevista en su doctrina de la metempsícosis: ${ }^{20}$

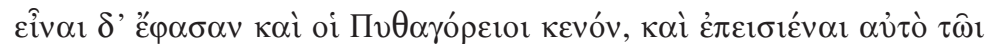

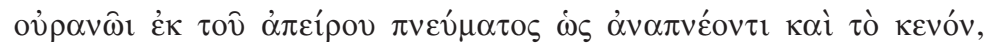
$\kappa \tau \lambda$.

Los pitagóricos decían que existe el vacío, y que éste, proveniente del soplo infinito, se introducía en el cielo como si éste respirara también el vacío, etc.

(Arist. Phys. $\Delta$ 6. 213b 22)

En vista de que el testimonio de Aristóteles se puede considerar bastante confiable, resulta también probable que en la doctrina de la respiración cósmica, que presenta una notable semejanza con la teoría pitagórica de la animación de los seres vivos, ${ }^{21}$ podamos señalar un cercano paralelo para la analogía

\footnotetext{
${ }^{20}$ Con este pasaje de Aristóteles concuerda asimismo, aproximándose notablemente hasta en la fraseología, una noticia extraída de su tratado (ahora perdido)

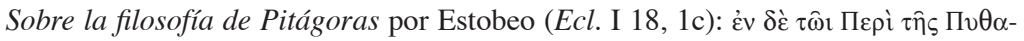

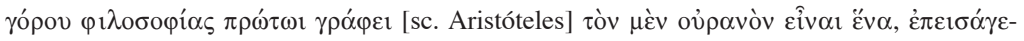

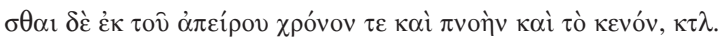

${ }^{21}$ La doctrina es atribuida concretamente al pitagórico Filolao de Crotona (s. V a.C.), que habría definido como armonía la relación entre alma y cuerpo, es decir,
} 
establecida por Anaxímenes entre la función del alma indivi-

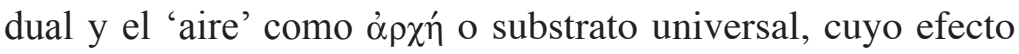
de cohesión a nivel cósmico es del todo equivalente al producido por el alma-soplo particular sobre cada ser humano: se trata, en efecto, como anticipábamos arriba, de un argumento que proyecta sobre el macrocosmos (esto es, el universo) los mecanismos fisiológicos observados en el microcosmos (el hombre). Ahora bien, el paralelismo así establecido entre los dos niveles cósmicos por parte de Anaxímenes y por Pitágoras (o sus discípulos), pese a su colocación en el marco de sendas cosmologías 'racionales', refleja con toda probabilidad un enfoque originado en una visión del mundo de clara matriz religiosa, que podemos calificar de 'animista', puesto que atribuye a la materia un rango divino por considerarla dotada de 'alma', es decir, de capacidad autónoma para moverse (y transformarse). En este sentido, las teorías hilozoístas presocráticas no difieren en el fondo de la visión propia de sectas religiosas del tipo de los órficos, cuya fuerte afinidad con el pitagorismo se revela de manera patente en su concepción de la inmortalidad del alma y de su transmigración de uno a otro

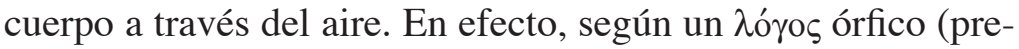
sumiblemente en hexámetros) que sirve de fuente a Aristóteles, dicha doctrina haría referencia a la naturaleza aérea del alma estableciendo un paralelo directo entre su entrada en los cuerpos de los animales y el mecanismo de la respiración:

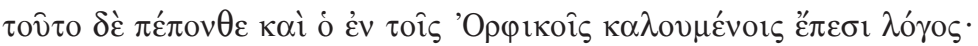

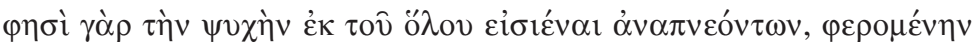
i $\pi \grave{o} \tau \hat{\omega} v \dot{\alpha} v \varepsilon \dot{\mu} \mu \omega v, \kappa \tau \lambda$.

como sintonía entre dos opuestos: al nacer, una suerte de 'apetito' impulsaría el cuerpo caliente a absorber el soplo frío del exterior, lo cual tendría el efecto de enfriarlo (Menon Anonymi Londin. [Suppl. Arist. ed. Ac. Bor. III 1] 18, 8 p. $31=$ Phi-

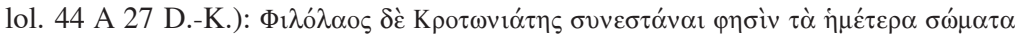

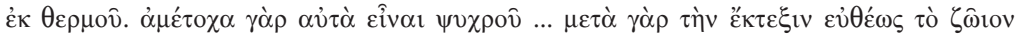

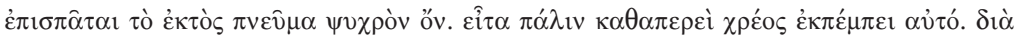

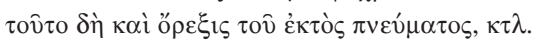


Esto fue lo que sucedió también con el discurso transmitido en la llamada epopeya órfica: dice, en efecto, que el alma de los seres que respiran penetra desde el universo, transportada por los vientos, etc.

(Arist. de anima, A 5, 410 b 28)

Ahora bien, mientras en el pasaje de la Física transcrito un poco más arriba Aristóteles reportaba como doctrina pitagórica el proceso de respiración cósmica, que equiparaba con el de la respiración fisiológica, ${ }^{22}$ antes todavía habíamos encontrado, en un pasaje de las memorias pitagóricas de Alejandro 'Polyhistor' transmitidas por Diógenes Laercio, que las almas son descritas justamente como "fragmentos de éter" caracterizados por las mismas "proporciones" numéricas de los vientos y que, como es comprensible, son pobladoras del aire. Por otro lado, tal y como vimos a propósito de los órficos, es justamente dicha naturaleza etérea de las almas la base de su transmisibilidad de un cuerpo a otro, de su viaje sobre las alas del viento, lo cual evidentemente forma parte del mecanismo de la metempsícosis y además se integra perfectamente como eslabón en un proceso 'natural' por su analogía con la respiración. Así pues, más todavía que el vehículo de la vida, en el aire tenemos el elemento vital por excelencia y por esa razón le fue atribuido un papel primordial en las doctrinas naturalistas y religiosas antes consideradas. Por su parte, la concepción del alma/soplo individual no representa más que un caso particular del principio, enunciado tanto por Anaxímenes como por los pitagóricos, del $\pi v \varepsilon \hat{\jmath} \mu \alpha$ cósmico o alma universal dadora de vida, un principio que, como es bien sabido, se arraigó profundamente en la mentalidad griega y reveló una gran fecundidad teórica: en efecto, tras ser retomada de múltiples formas en el ámbito de la escatología popular religiosa, dicha noción habría de conocer todavía una nueva vigencia en el

\footnotetext{
${ }^{22}$ Phys. $\Delta$ 6. 213b 22 (véase arriba el texto).
} 
marco del último gran sistema presocrático, la doctrina naturalista elaborada por el médico y científico del siglo v a.C., Diógenes de Apolonia. En efecto, éste identificó en el aire, en virtud del papel que juega en la respiración animal, el principio vital por excelencia, la $\psi v \chi \eta ́$, pero además de esto lo vio como la fuente no sólo de las facultades sensoriales, sino

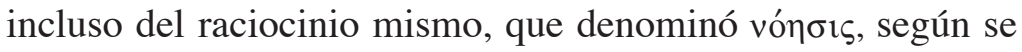
desprende de sus propias palabras:

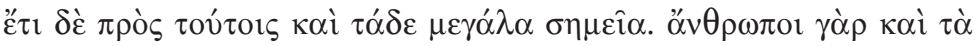

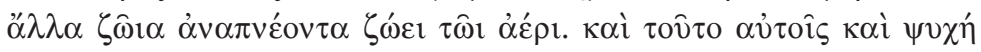

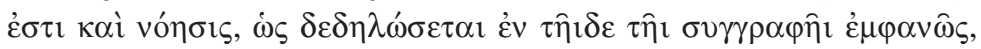

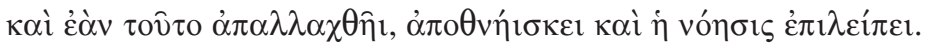

Además de esto hay los indicios de peso que siguen. En efecto, los hombres y los demás animales que respiran viven con el aire. Y éste es para ellos tanto el alma como la facultad de pensar, como se pondrá claramente en evidencia en este tratado, y si éste se aleja [aquellos] mueren y la facultad de pensar viene a menos.

(Diog. Apoll. 64 B 4 D.-K.)

Dejando de lado por el momento la asociación entre fuerza

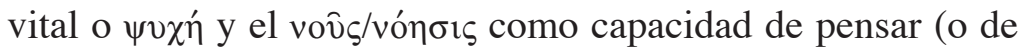
formarse imágenes mentales), es conveniente examinar ahora la fortuna del alma etérea en el campo de las creencias religiosas. Según una idea que vimos típica del orfismo y del pitagorismo, el alma fue concebida como un espíritu rarefacto llegado al cuerpo desde lo alto con el viento, visión que acabó cristalizándose en la muy famosa doctrina de la dicotomía fundamental alma/cuerpo, la cual fue característica no sólo del helenismo clásico y posterior, sino dejó además una impronta conceptual muy fuerte sobre el cristianismo judaico. En efecto, según la oposición polar que establecen ya los testimonios arcaicos de dicha doctrina, el alma recorre una trayectoria aérea en su viaje de transmigración, pues su origen está en el cielo y, además, en su calidad de elemento vital e impere- 
cedero, se une temporalmente al cuerpo caduco constituido de materia terrena, donde permanecerá aprisionada como en una tumba durante un cierto tiempo, para después liberarse y regresar al dominio celeste. ${ }^{23}$ Estamos, pues, frente a una concepción órfica o pitagórica que gozó de una gran fortuna, como documentan numerosos testimonios (cabe destacar aquí los múltiples pasajes platónicos en que se atribuye a Sócrates), ${ }^{24}$ según la cual el cuerpo sería una especie de cárcel temporal para el alma, es decir, una envoltura mortal que aquélla abandonará una vez expiada su pena para luego volver a revolotear libre en el aire, doctrina que aparece ligada notoriamente con el nombre del pitagórico Filolao de Crotona. ${ }^{25}$ Sin embargo, no se puede afirmar en este caso que se trate de una concepción exclusiva ni del pitagorismo ni del orfismo, pues la creencia en la dualidad cuerpo/alma, más precisamente en la conjunción temporal de dos elementos que se encuentran en oposición polar, está ampliamente atestiguada en la época arcaica y clásica. En efecto, frente a los abundantes e indudables testimonios proporcionados por los textos de inspiración órfico-pitagórica, ${ }^{26}$ existe también una consistente documenta-

\footnotetext{
${ }^{23}$ Una formulación elegante de este principio en Epich. fr. 213 K.-A. (= 23 B 9

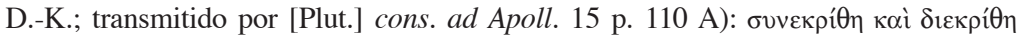

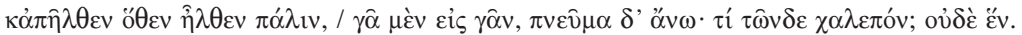

${ }^{24}$ Compárese por ejemplo Plat. Phaed. 61e y Gorg. 493a; en Plat. Men. 81a81e, Sócrates justifica el empleo de su método 'mayeútico' con base en la doctrina

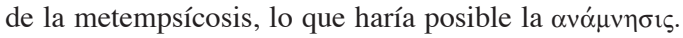

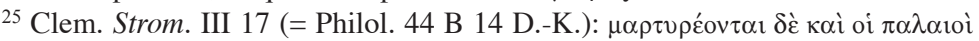

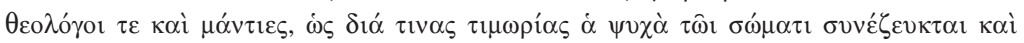

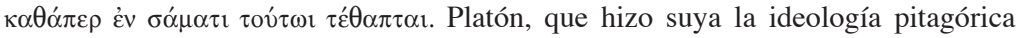
acerca de la inmortalidad del alma y que vuelve una y otra vez sobre el tema en sus diálogos socráticos, confirma también el origen pitagórico de la concepción del cuerpo como prisión del alma, atribuyéndola nada menos que a la enseñanza de Filolao (cfr. los dos primeros pasajes platónicos citados en la nota anterior).

${ }^{26}$ Para la presencia de esta concepción en el pitagorismo antiguo cfr. [Pyth.]

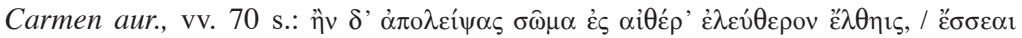

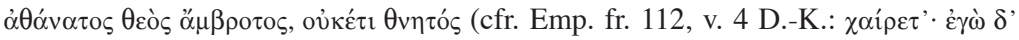

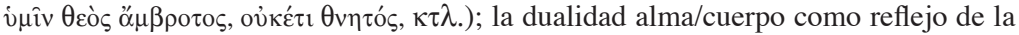
oposición cósmica cielo/tierra aparece también claramente en la laminilla órfica de
} 
ción que confirma el arraigo de dicha concepción dualista del hombre en los siglos VI y V a.C., de lo que se pueden aducir elocuentes ejemplos literarios y epigráficos. ${ }^{27}$

Así pues, nos encontramos aquí frente a un elemento doctrinal que habría de quedar asociado tradicionalmente con la concepción helénica del hombre, y que, bajo el decisivo empuje recibido por parte del platonismo, pasaría a formar parte de las constantes culturales de Occidente. Se trata, como ya hemos anunciado, de la concepción del hombre como un conglomerado de dos componentes: el cuerpo, de origen terreno, que acoge temporalmente en su seno al alma, de origen celeste. Dicho enlace se disuelve cuando el alma abandona la pesada envoltura corpórea, que es reabsorbida por la tierra, y emprende el vuelo hacia lo alto para reunirse con el éter inmortal, su fuente y destino final. Ahora bien, pese a la considerable antigüedad que, como vimos, se debe atribuir a la concepción pneumática del alma y a la doctrina de la cíclica fusión y separación de dos elementos heterogéneos (cuerpo/ alma) operada en el hombre individual, su presencia registró un notable incremento a partir de la segunda mitad del siglo $\mathrm{V}$ a.C., hecho que se puede poner en relación con la creciente difusión de la enseñanza pitagórica, emanada desde el sur de Italia, hacia la parte oriental del mundo griego (incluida Atenas), a donde la habrían llevado los prófugos supervivientes de las matanzas perpetradas en contra de las fraternidades pitágoricas por parte de las facciones contrarias a su hegemonía política en las ciudades de la Magna Grecia.

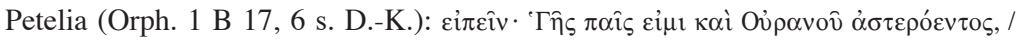

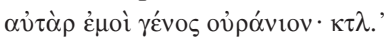

${ }^{27}$ Entre los testimonios literarios, cabe resaltar Eur. fr. 839 Kann. vv. 8 ss.:

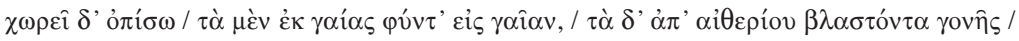

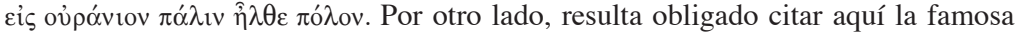
inscripción (sobre la cual véase E. Rohde, Psyche, vol. II, p. 258, n. 2) en honor de los atenienses caídos en Potidea en 432 a.C. (C.I.A. 1, 442; ahora en P. A. Hansen [ed.], Carmina epigraphica Graeca saeculorum VIII-V a. Chr. n., Berolini-Novi

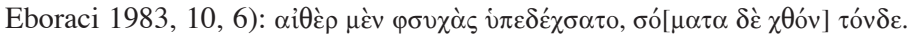


En vista de la extensa especulación sobre el alma documentada para los pitagóricos, no resultará en absoluto extraño constatar que algunas de las primeras formulaciones explícitas de la asociación del alma con las funciones intelectivas se hayan producido también en el ambiente pitagórico magnogreco. En efecto, según los testimonios que hemos presentado arriba, los pitagóricos pensaban que el alma individual, en cuanto fragmento inmortal del alma cósmica, estaba dotada de la capacidad de transmigrar de uno a otro cuerpo, es decir, era la portadora de la energía vital que animaba a éste. Sin embargo, más aún que una mera chispa divina dadora de vida, el alma era aparentemente concebida por Pitágoras y sus seguidores como la sede de capacidades de orden más propiamente intelectual, pues de acuerdo ya con los testimonios más antiguos sería en ésta donde se almacenarían los conocimientos adquiridos a lo largo de las sucesivas reencarnaciones, en especial de los personajes meritorios, quienes tendrían acceso a dicho caudal de saber acumulativo a través del ejercicio de la óvó $\mu v \eta \sigma ı \varsigma^{28}$ Asimismo, a consecuencia también de la doctrina de la metempsícosis, el alma parece haber sido concebida nada menos que como la fuente de la identidad personal, al grado de llevar consigo los rasgos caracterizantes que permiten reconocer al individuo pese

\footnotetext{
${ }^{28}$ Hay un probable testimonio de esto en un fragmento de Empédocles, transmitido en las biografías de Pitágoras escritas por los neo-platónicos Porfirio y Jámblico, que describe las capacidades intelectivas extraordinarias de una figura veneranda identificada por ellos como Pitágoras, poniendo énfasis en su "riqueza de ingenio" y en su capacidad de ver cada una de las cosas en el lapso de sus

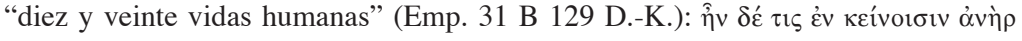

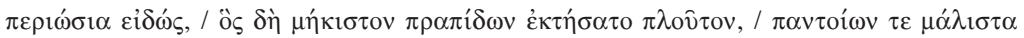

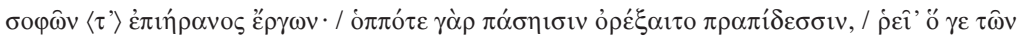

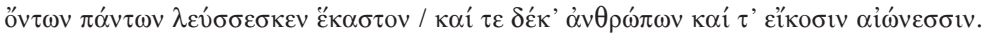


a encontrarse bajo una forma física inesperada, en virtud del continuo cambio de cuerpo a que está sujeto. ${ }^{29}$

Por otro lado, también la antigua concepción del alma pneumática muestra claras connotaciones intelectuales en otros presocráticos, sobre todo a partir de Anaxímenes, para quien el aire, en tanto substrato de todas las cosas, desempeña a nivel cósmico las mismas funciones que el alma individual en cada persona, es decir, es responsable de la cohesión y organización del todo. Se trata, en efecto, de un principio vital que, a más de imprimir el impulso motriz a la materia, contiene simultáneamente la capacidad de dar lugar a una disposición ordenada de las cosas, de integrarlas en un cosmos. Esto concuerda plenamente con la concepción que vimos propia del pitagorismo antiguo, según la cual, al final de la progresión cosmogónica que conduce de los números (surgidos de la interacción entre el "Uno" - o "mónada" - y la "Díada" indeterminada) a los "cuatro elementos" (fuego, agua, tierra, aire), aparece un

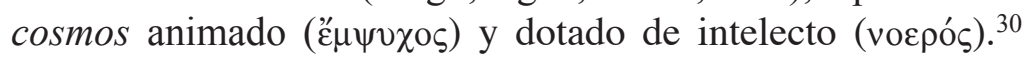
Asimismo, la especulación pitagórica acerca de los números como principio de todas las cosas del universo desembocó en la veneración especial de ciertas cifras, a las que atribuyeron propiedades especiales: cabe destacar aquí el lugar especial ocupado por el diez, denominado perfecto, ${ }^{31}$ cuya génesis se visualizó en la adición de los cuatro primeros naturales $(1+2$ $+3+4=10$ ) y que, representado en forma figurada a través de

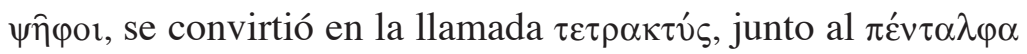

\footnotetext{
${ }^{29}$ Esto se puede inferir, en efecto, de la parodia que de Pitágoras hace Jenófa-

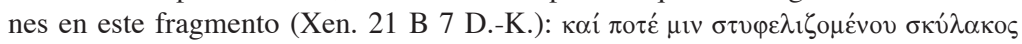

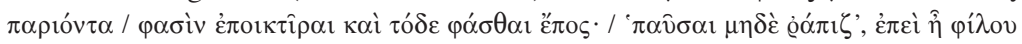

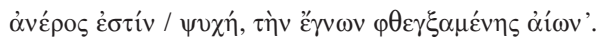

${ }^{30}$ Véase Diog. Laert. VIII 24-33 (= Pyth. Schule 58 B 1a D.-K.), citado arriba en el texto.

${ }^{31}$ Entre los abundantes testimonios acerca de la veneración del diez entre los pitagóricos cabe destacar un detallado pasaje de los Theolog. Arithm., p. 74, 10 (= Philol. 44 A 13 D.-K.), así como el fragmento Philol. 44 B 11 D.-K.
} 


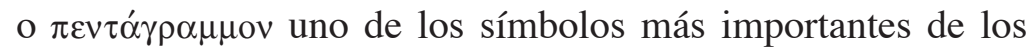
pitagóricos. ${ }^{32}$ En efecto, el 4, que como vimos era en potencia también el 10, se convirtió en el eje de un simbolismo que, consagrado en el máximo juramento de los pitagóricos, ${ }^{33}$ iden-

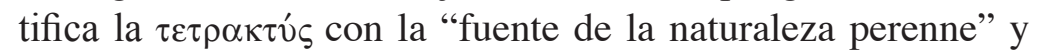
asocia asimismo el 4 con el alma, en cuanto estaría compuesta

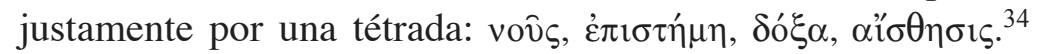
Estos cuatro elementos del alma, por su parte, a más de ser la fuente de todas las artes y ciencias, lo serían también de la racionalidad misma del hombre. ${ }^{35}$ Por lo tanto, al parecer tenemos aquí ya plenamente desarrollada la concepción según la cual el alma tiene a su cargo todas las funciones psíquicas e intelectivas del organismo vivo, pluralidad operativa que, desde el punto de vista antiguo, se explica hablando de "partes del alma". Según ésta concepción, en efecto, el alma se instala en el cuerpo, que de otro modo estaría inerte, y una vez dentro de éste desempeña múltiples papeles, pues a más de proveer la chispa vital que lo impulsa, monopoliza y controla también la producción de todos los impulsos más propiamente psíquicos, como las pasiones, los afectos y la sensación, e incluso las funciones intelectivas, como el raciocinio y la adquisición del conocimiento.

Así pues, a partir de las consideraciones anteriores, estamos ahora en posición de señalar un claro vínculo entre las concep-

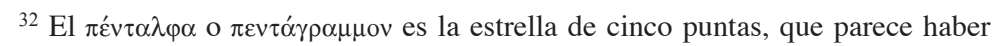
sido construida a partir de la prolongación de las diagonales de un pentágono regular y fungió como una especie de 'logotipo' de la escuela pitagórica.

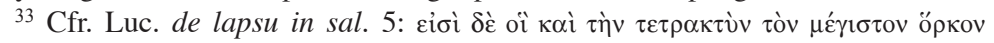

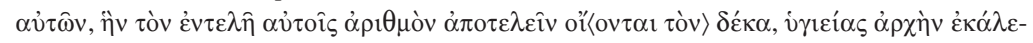

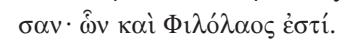

${ }^{34}$ La tetrapartición del alma aquí descrita tiene un paralelo también pitagórico en los cuatro principios del ser racional enunciados en Philol. 44 B 13 D.-K.

${ }^{35}$ Aquí el testimonio más completo es Aët. I 3, 8 (D. 280) (= Pythag. Schule 58 B 15 D.-K.), que por cierto transmite el juramento pitagórico en la siguiente forma:

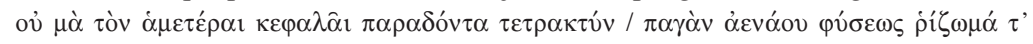
É $\chi 0 v \sigma \alpha v$ - para los pasajes paralelos véanse las referencias indicadas por DielsKranz ad loc. 
ciones del alma descritas anteriormente y la asociación, constante en el pensamiento presocrático, entre el papel de subs-

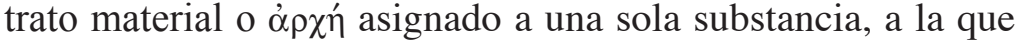
se atribuye justamente la función de dar el impulso motriz y la vida y se designa a menudo con el preciso nombre de "alma", y el de ser ésta misma el principio inteligente de organización de las cosas, responsable de controlar todo y de disponer cada elemento en su justo sitio, dando lugar a un cosmos.

Ahora bien, en vista de la difusión que dicha concepción hilozoísta parece haber alcanzado en el pensamiento presocrático, es natural esperar que la asociación arriba descrita estuviera presente también en otros autores del mismo período, situación que de hecho se verifica con especial flagrancia nada menos que en Heráclito, cuyo sistema de pensamiento exhibe una particular mezcla de racionalismo y misticismo en buena parte comparable a la del pitagorismo. Es bien conocido, en efecto, que el filósofo de Éfeso, tras haber señalado en

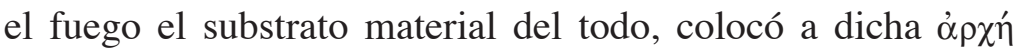
en el centro de un complejo ciclo de transformaciones que, sin embargo, obedecen a una ley inexorable y perfectamente regular. ${ }^{36}$ Más aún, Heráclito ve en la vida, tanto a nivel cósmico como a escala humana, un juego de fuerzas contrarias que entablan una lucha incesante por prevalecer una sobre la otra, según un principio que atinadamente equiparaba al modelo de la guerra, ${ }^{37}$ confrontación que veía más precisamente sujeta a un equilibrio, ciertamente dinámico pero aun así contenido dentro de límites precisos, en donde nada rebasa su justa medida. $^{38}$

\footnotetext{
${ }^{36}$ Cfr. Arist. Metaph. A 3, 984a 7 (= Hipp. 18 A 7 D.-K.) y Simpl. Phys. 23, 33 (Heraclit. 22 A 5 D.-K.).

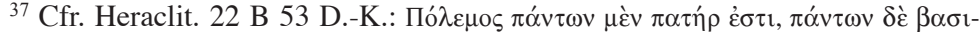

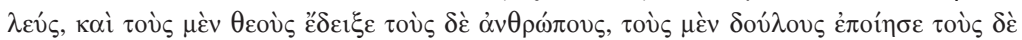

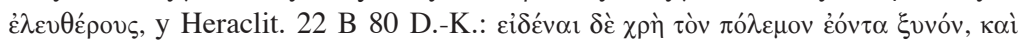

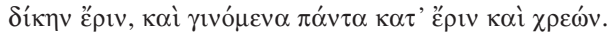

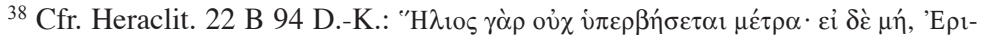

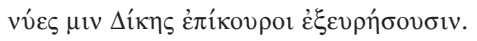


Así pues, el todo según Heráclito es la manifestación de un orden preciso y está animado por una vitalidad cuyo símbolo es el fuego eterno, pero en virtud de ese mismo orden está también sujeto a un ciclo de encendido y apagado por medidas, ${ }^{39}$ en que el fuego funciona ni más ni menos como el sustrato o principio de trueque a partir del cual y hacia el cual todos los demás componentes del mundo, que se miden justamente con base en él, ${ }^{40}$ cambian según una proporción fija. Con todo, las transformaciones que tienen lugar en este proceso están perfectamente definidas y se insertan en un ciclo preciso, sucediéndose ahí en un orden y verificándose con cuotas absolutamente regulares: ${ }^{41}$ más aún, las mutaciones o $\tau \rho о \pi \alpha i ́$ del fuego siguen una dirección determinada y luego, tras alcanzar el límite máximo en un sentido, invierten la marcha y toman el mismo camino pero en sentido opuesto, pues, según el propio Heráclito, la "vía ascendente y descendente es una y la misma". ${ }^{42}$ Así, a través de la infalible compensación de una transformación ocurrida en un sentido con su inversa en sentido opuesto, se regresa siempre al estado original de equilibrio y se mantiene constante el orden del mundo, de modo que aquél "reposa mientras se transforma". ${ }^{43}$ Así pues, los fragmentos de Heráclito parecen proyectar un panorama en que, en virtud de un ciclo recurrente, una vez concluido todo el proceso cada cosa vuelve a su punto de partida: el equilibrio original queda así siempre restablecido en virtud de la semejanza que dicha

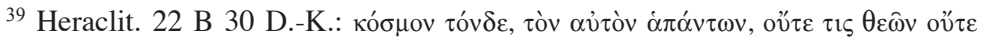

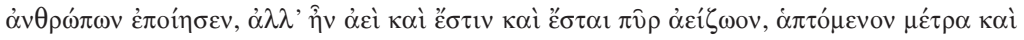

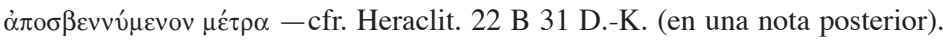

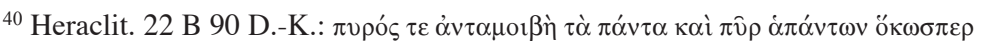

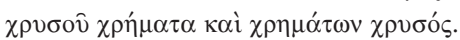

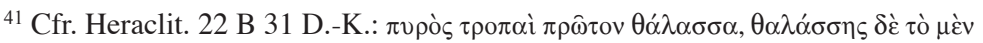

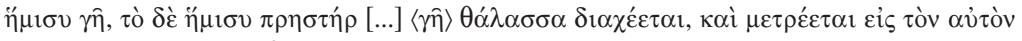
$\lambda$ ó

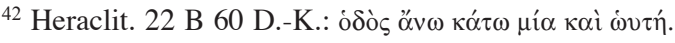

${ }^{43}$ Es así como Plotino refiere la intuición de Heráclito en Enn. IV 8, 1 (= Hera-

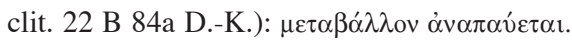


transformación cíclica guarda con la circunferencia, en que "el principio y el fin coinciden" ${ }^{44}$ Por consiguiente, todas las alteraciones se contrarrestan mutuamente y apuntan al mantenimiento del orden, sin el cual el cosmos no sería más que "un montón de cosas regadas al azar". ${ }^{45}$

En consideración de lo anterior, se impone la conclusión de que, a los ojos de Heráclito, detrás del perenne conflicto que enfrenta a los opuestos, el todo constituye un conjunto organizado y perfectamente equilibrado en el que la palabra clave es el orden, un orden que se identifica por cierto con el proyecto implícito en el substrato material, el fuego eterno, que es también el motor fundamental de todas las cosas. Dicho substrato

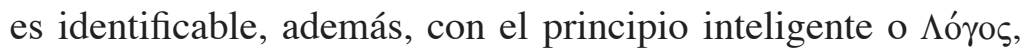
el cual constituye en el sistema de Heráclito una ley universal que controla el desarrollo y, llegado el momento, el final de todo. En efecto, el mismo fuego justiciero que dicta el desti-

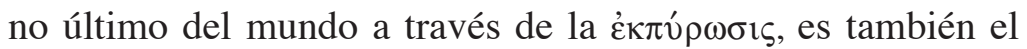
responsable de su ordenamiento o disposición cósmica, de lo cual nos da testimonio un comentario sobre algunos fragmentos de Heráclito que capta con bastante fidelidad el espíritu de su doctrina:

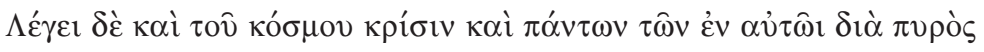

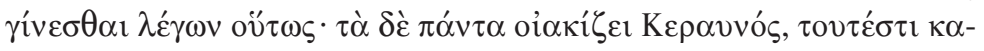

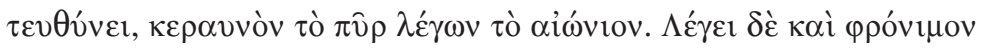

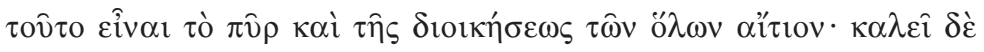

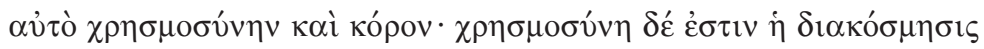

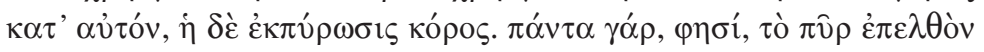

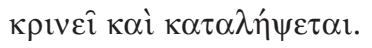

Sostiene que el juicio del mundo y de todo lo que hay en él tiene lugar a través del fuego, expresándolo de este modo: "El Rayo timonea todas las cosas", esto es, las dirige, llamando 'rayo' al

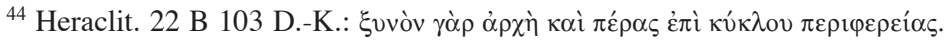

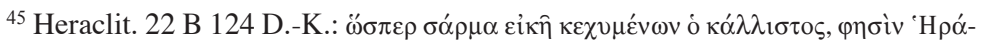

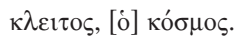


fuego eterno. Sostiene también que dicho fuego tiene entendimiento y es responsable de gobernar el todo. No obstante, lo llama "menester y saciedad": según él, 'menester' sería la disposición ordenada del mundo, mientras que 'saciedad' sería la conflagración. Dice, en efecto, que "el fuego vendrá a juzgar y a hacerse cargo de todo".

(Hippol. IX, 10 = Heraclit. 22 B 63-66 D.-K.)

La facultad intelectiva reconocida al fuego por nuestro comentarista, aunada a la capacidad directiva que, según la metáfora aparentemente acuñada por el propio Heráclito (oi $\alpha \kappa i \zeta \varepsilon 1: ~ ' t i-$ monea'), este filósofo atribuye expresamente a su principio, delata la estrecha filiación del sistema del efesio con las concepciones de los pensadores que, según vimos, asociaron la

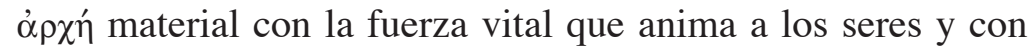
el plan racional que subyace a la organización del todo. Por lo tanto, esto pone al fuego heracliteo en el mismo plano que el aire de Anaxímenes en su papel de alma cósmica (que también aparece en las doctrinas pitagórica y órfica), en la medida en que estamos autorizados a identificar en el fuego heracliteo un proyecto inteligente, la fuente misma del orden del mundo. Por otra parte, la identidad fuego $=\log$ os que se desprende de la caracterización del fuego en el pasaje anterior como un ser capaz de pensar, encuentra por cierto su confirmación en otros reportes doxográficos sobre Heráclito, como el muy detallado de Sexto Empírico, quien se refiere a la concepción del logos en términos que corresponden enteramente a los aplicados al fuego en el texto de arriba:

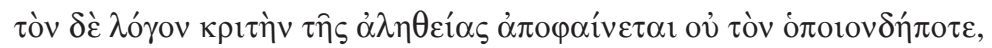

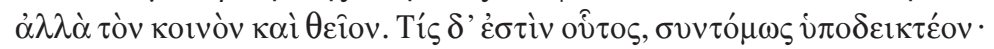

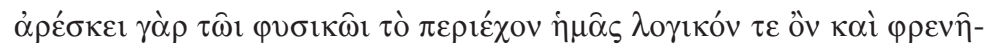

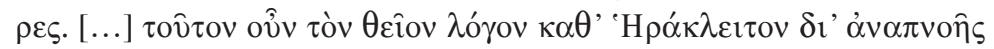

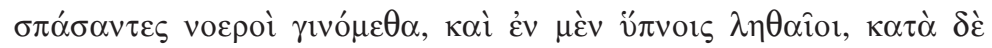

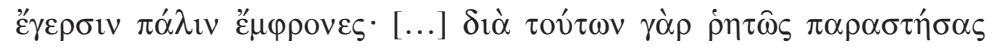

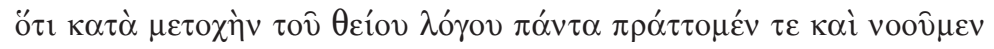




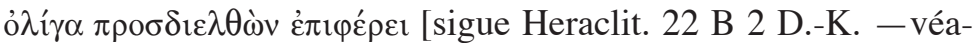

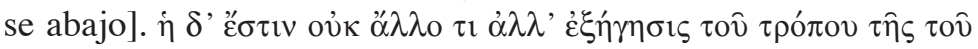

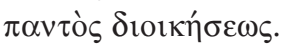

[Heráclito] revela como árbitro de la verdad no al logos cualquiera, sino al que es común y divino. Es preciso indicar de manera sucinta la identidad de éste: la opinión de nuestro filósofo naturalista es que se trata de lo que nos envuelve, pues es racional y dotado de juicio. [...] Según Heráclito, al aspirar ese logos divino a través de la respiración adquirimos la inteligencia, y en los sueños la olvidamos, para volver a estar cuerdos al despertar. [...] Tras haber mostrado perspicuamente con estas palabras ${ }^{46}$ que todo lo hacemos y pensamos por participación del logos divino, y tras haber expuesto algunas pocas cosas más, agrega:

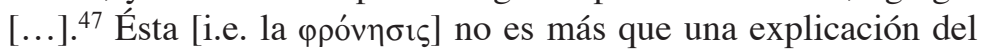
modo en que es gobernado el mundo.

(Sext. adv. math. VII 127-133 = Heraclit. 22 A 16 D.-K.)

De la consideración de los dos pasajes arriba citados, donde

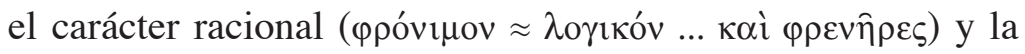

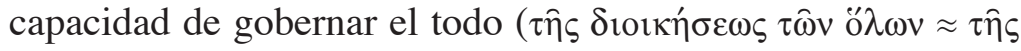

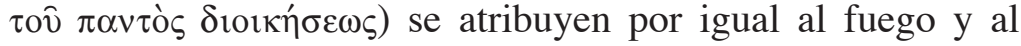
logos, parece poder establecerse sin lugar a dudas la ecuación fuego $=\operatorname{logos} .{ }^{48}$ Por otra parte, en el hecho de que el logos sea concebido como una substancia dotada de razón que nos rodea y cuyo entendimiento se transfiere a los seres individuales justamente a través del mecanismo de la respiración, tenemos

\footnotetext{
${ }^{46}$ Se refiere al trozo que omitimos en nuestro texto, que cita Heraclit. 22 B 1

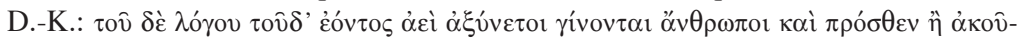

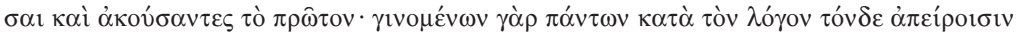

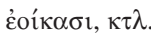

${ }^{47}$ En este punto cita Heraclit. 22 B 2 D.-K., que transcribimos y traducimos más abajo en el texto.

${ }^{48}$ Así opinan W. K. C. Guthrie, A History of Greek Philosophy, Cambridge 1962, vol. I, p. 432; y G. R. S. Kirk, Heraclitus: the Cosmic Fragments, Cambridge 1954, p. 396: "Unchanged fire is the most active kind of matter and in its purest form or aither (so we may conjecture) it possesses directive capacity, it is the embodiment of the Logos ... and it is wise".
} 
un paralelismo insoslayable para la animación cósmica e individual destacada arriba en las cosmogonías presocráticas de Anaxímenes, Pitágoras, Diógenes de Apolonia y los órficos. Por consiguiente, parece perfectamente legítimo establecer para el sistema de pensamiento de Heráclito la equivalencia tripartita fuego $=\log o s=$ alma. En efecto, que Heráclito concebía el alma como idéntica al substrato ígneo de donde surgen todas las cosas y a donde éstas regresan finalmente al disolverse en

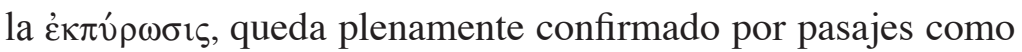
los siguientes, en que los términos 'fuego' y 'alma' resultan intercambiables:

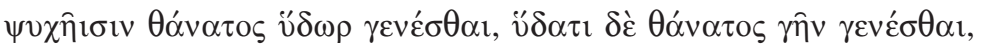

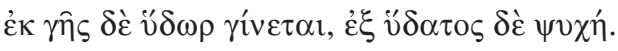

La muerte para las almas es convertirse en agua, para el agua la muerte es convertirse en tierra, de la tierra surge el agua y del agua el alma.

(Heraclit. 22 B 36 D.-K.)

Con el empleo de la palabra 'alma' en este contexto, donde aparece insertada expresamente en un proceso físico de metamorfosis sucesivas en las que el trastrocamiento de una substancia anterior en otra nueva conlleva la 'muerte' o disolución de la primera, ${ }^{49}$ cabe comparar en especial otro fragmento de $\mathrm{He}$ ráclito que describe el ciclo de las $\tau \rho \circ \pi \alpha i ́$ o mutaciones del fuego: ${ }^{50}$

\footnotetext{
${ }^{49}$ La concepción del alma que se disuelve al volverse más húmeda se atribuye de nuevo a Heráclito en Numen. fr. 35 Thedinga, apud Porphyr. antr. nymph. 10:

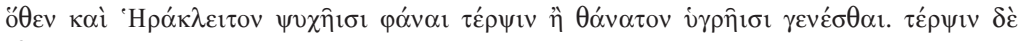

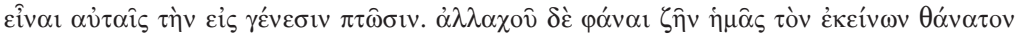

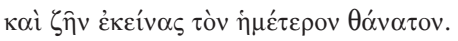

${ }^{50}$ Acerca del mismo ciclo de transformaciones nos informa una serie de paráfrasis, que reproducen con mayor o menor exactitud la concepción de Heráclito.

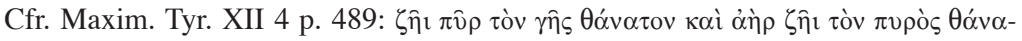

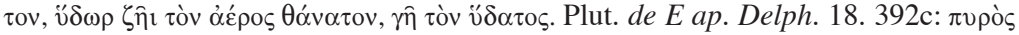

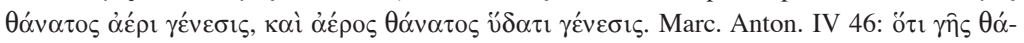

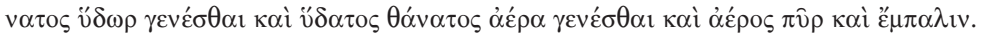




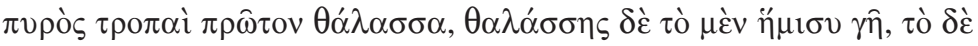

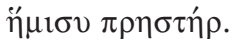

Las mutaciones del fuego: primero mar, del mar la mitad se convierte en tierra, la mitad se vuelve incandescente.

(Heraclit. 22 B 31 D.-K.) $)^{51}$

En especial, Heráclito parece haber insistido, enfocándola desde diferentes perspectivas, en la conversión del agua/mar en fuego/alma, con la salvedad de que parece haber aplicado a esta última el nombre de $\alpha v \alpha \theta v \mu i ́ \alpha \sigma 1 \varsigma,{ }^{52}$ término que la define por cierto como una exhalación caliente y seca, presumiblemente por parecerle esta condición, con todo y que tiene en el agua su punto de partida, la única congruente con la naturaleza ígnea de su principio. ${ }^{53}$ Aristóteles, por su parte, en un recorrido por las diferentes concepciones del alma sostenidas por los pensadores antiguos, confirma la interpretación anterior de la doctrina de Heráclito, en el sentido de que el alma, visualiza-

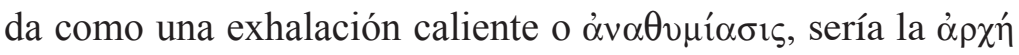
dotada de eterno movimiento que constituye la base de todas las cosas. ${ }^{54}$ Adicionalmente, hay, testimonios que establecen una conexión entre la $\alpha \dot{v} \alpha \theta v \mu i ́ \alpha \sigma 1 \varsigma$ cósmica en calidad de alma universal resultante de la mutación en fuego de la humedad que hay en el mundo y la correspondiente $\alpha \dot{v} \alpha \theta \nu \mu i ́ \alpha \sigma ı \varsigma$ particular

\footnotetext{
${ }^{51}$ Nuestra fuente en este caso es, como para muchos otros fragmentos de Heráclito, Clemente de Alejandría (V 105 [II 396, 13]), quien glosa del siguiente modo

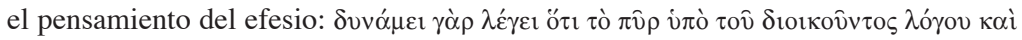

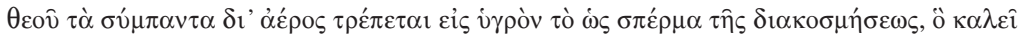

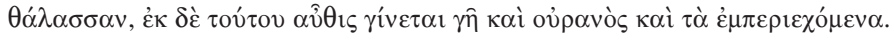

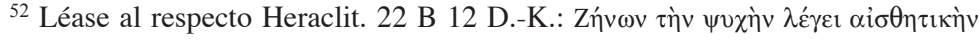

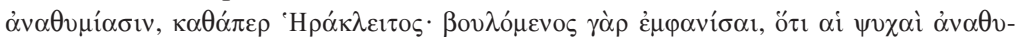

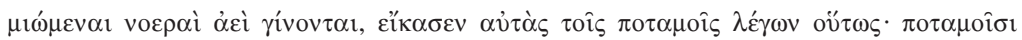

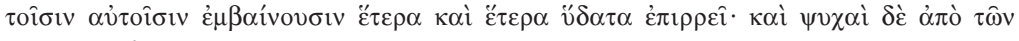

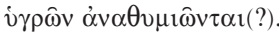

${ }^{53}$ Es indicativo de esta elección lexical el hecho de que $\alpha \dot{v} \alpha \theta u \mu i ́ \alpha \sigma ı \varsigma$ se oponga

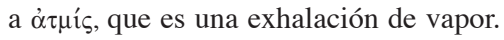

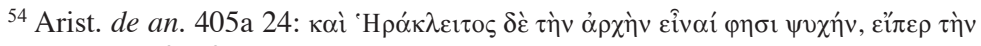

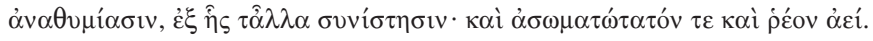


o alma individual, emparentada con el alma cósmica de la que proviene y es fiel reflejo a escala. ${ }^{55}$ Por lo tanto, la concordancia de estos testimonios con los fragmentos de Heráclito arriba citados demuestra de manera virtualmente incontrovertible

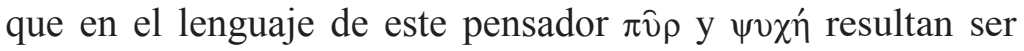
simplemente dos términos para designar una misma realidad conceptual, pues ambos son aplicables indistintamente al substrato primigenio que da origen a todo y en el que al final todo se disuelve, atravesando por una serie de transformaciones rigurosamente codificadas. Por otro lado, según señalamos

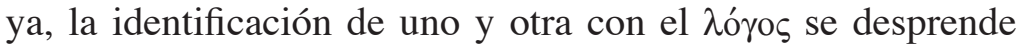
netamente de la atribución al fuego de un carácter racional y de la concepción del $\lambda$ ó envuelve y de la que recibimos la inteligencia a través de la respiración.

Estamos, en suma, ante una muestra indiscutible de la característica indiferenciación presocrática entre material y espiritual, misma que señalamos antes a propósito de otros pensadores arcaicos, la cual aparece en la doctrina de Heráclito asociada con otra concepción muy difundida en el pensamiento griego antiguo. En efecto, según hemos podido señalar arriba a propósito de diferentes doctrinas presocráticas, una constante de las cosmogonías antiguas era el establecimiento de un paralelismo entre el universo y el individuo. A partir de aquí se especulaba que así como hay una substancia impalpable que nos rodea y que absorbemos al interior de nuestro cuerpo al respirar, recibiendo de ella la fuerza vital junto con la capacidad de pensar (o inteligencia), así también hay una substancia que abraza al cosmos ( iò $\pi \varepsilon \rho 1 \varepsilon ́ \chi o v)$, constituida de la forma más

\footnotetext{
${ }^{55}$ Esto se puede inferir de testimonios como los agrupados bajo Heraclit. $22 \mathrm{~A}$ 15 D.-K., esto es Macrob. Somn. Scip. 14, 19: (animam) Heraclitus physicus scin-

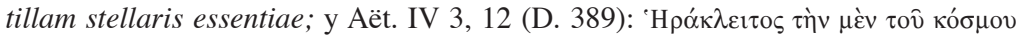

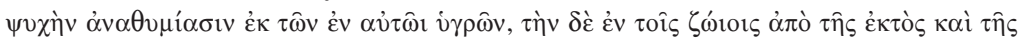

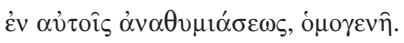


pura de la materia o, más precisamente, del residuo de la ópxń primigenia, fuente eterna (es decir, divina) de la vida cósmica y sede del principio inteligente que gobierna todas las cosas. Esto fue reconocido ya por Aristóteles en la Física, en el marco de su exposición acerca de las categorías fundamentales de la ciencia que se ocupa de la naturaleza (es decir, la 'física'), don-

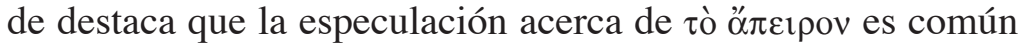
a la mayor parte de los presocráticos, quienes identificaron en éste el origen del todo. ${ }^{56}$ Un poco más adelante, el Estagirita se refiere con mayor precisión a dicha concepción presocrática de

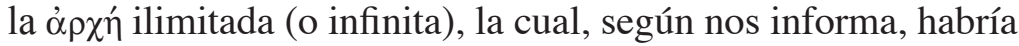
sido vista por los filósofos naturalistas antiguos como un ser divino, esto es, inmortal e incorruptible, que abarca o envuelve todo y que todo controla. ${ }^{57}$ Sobre este aspecto encontramos una confirmación puntual en varios fragmentos de Heráclito, que nos hablan de un principio racional que tiene a su cargo la dirección de todo y del que los hombres toman prestada la capacidad de pensar, la cual es por lo tanto la misma para todos, aunque sin ser propia de ninguno, pues su fuente está en el

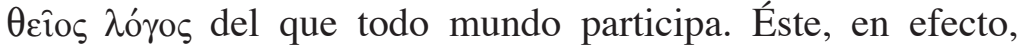
parece ser el sentido que con mayor probabilidad se puede atribuir al fragmento identificado como el exordio del escrito de Heráclito, ${ }^{58}$ donde echa en cara a los hombres su carencia de entendimiento antes y después de haber escuchado el $\lambda$ ó $\gamma$ s, por lo que obran sin tener conciencia de lo que hacen, sometidos al imperio de dicha ley que controla todo. De ahí que el filósofo

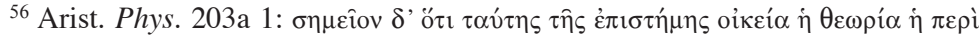

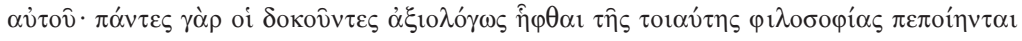

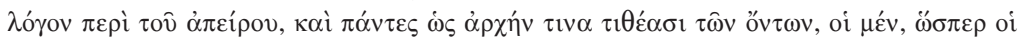

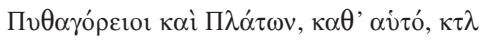

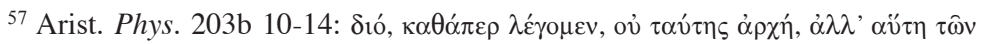

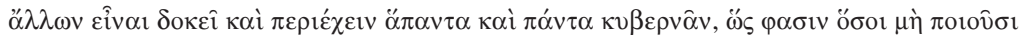

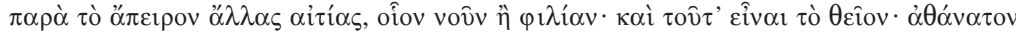

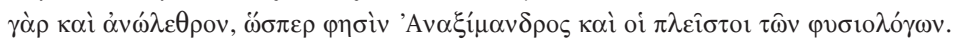

${ }^{58}$ Heraclit. 22 B 1 D.-K.
} 
de Éfeso fustigue en otro fragmento a la masa, que se engaña creyendo que piensa autónomamente, sin percatarse de que

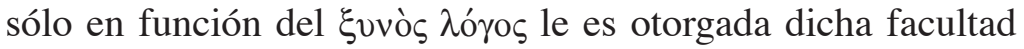
de pensar:

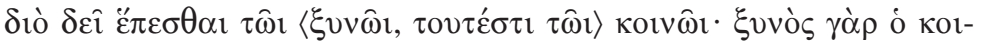

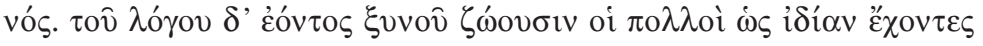

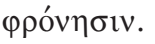

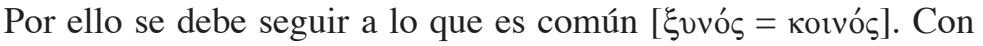
todo, aunque el logos sea común, la muchedumbre vive como si tuviera un pensamiento propio.

(Heraclit. 22 B 2 D.-K.)

Sin embargo, al igual que gran parte de las enseñanzas del efesio, también esta doctrina heraclitea del origen común de todo pensamiento en el $\lambda$ ó secuencia paradójica o cuando menos imprevisible en un primer acercamiento. En efecto, una serie de reportes doxográficos nos transmite una opinión de Heráclito según la cual el hombre carece por naturaleza de razón, la cual se encontraría solamente en la substancia que lo envuelve, que es de naturaleza divina. ${ }^{59}$ Se trata, a todas luces, de la versión heraclitea de una antigua y difundida concepción poética, ${ }^{60}$ cuyas raíces se remontan a la épica, según la cual el conocimiento verdadero es monopolio de los dioses, mientras que los hombres son criaturas que "no saben nada", sujetas a la voluntad de aquéllos. ${ }^{61}$ Es sin duda en apego a esta noción arcaica que en

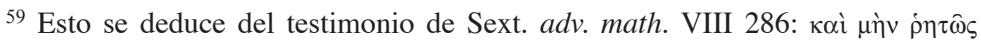

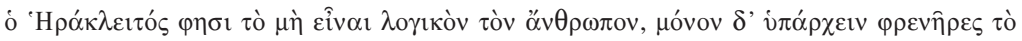

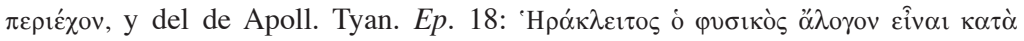

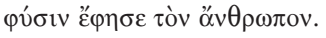

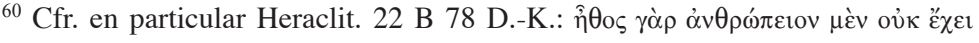

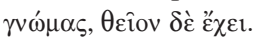

${ }^{61} \mathrm{La}$ concepción de la mutabilidad y de la falibilidad humanas, eficazmente

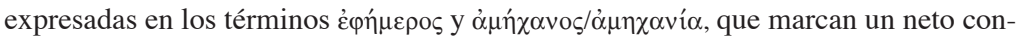
traste con la omnipotencia y la eternidad divinas, es un lugar común bien conocido de la poesía griega arcaica, sobre el cual conviene remitir a la brillante exposición
} 
los fragmentos heracliteos una y otra vez sale a flote la idea de que los hombres son semejantes a personas que duermen y, por ende, no cobran conciencia de ("olvidan") lo que les pasa, ${ }^{62} \mathrm{o}$ bien que estando despiertos viven en un mundo común, mientras que al dormirse cada quien se retira al suyo propio. ${ }^{63}$ Es posible, además, que Heráclito haya conectado la concepción tradicional apenas mencionada, según la cual las facultades cognoscitivas humanas serían sumamente limitadas en comparación con la capacidad divina de abarcar todo el saber sin esfuerzo alguno, con la dimensión cósmica del alma, concebida ésta como el principio inteligente de organización del universo, en el siguiente fragmento:

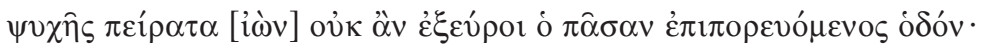

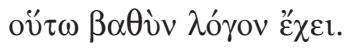

Aquél que recorre todos los caminos no podría descubrir [a medida que avanza] los límites del alma, pues ésta posee un logos tan profundo. ${ }^{64}$

(Heraclit. 22 B 45 D.-K.)

Es natural, en efecto, que Heráclito, quien reprocha severamente de carencia de razón incluso a intelectuales notables que el vulgo considera sus autoridades, condenando expresamente el método acumulativo del saber que aquéllos practican, consistente en una multiplicación de las pesquisas por

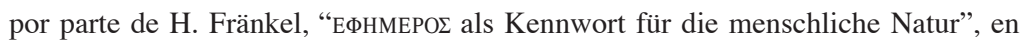
Wege und Formen frühgriechischen Denkens, München $1955^{1} ; 1960^{2}$, pp. 23-39.

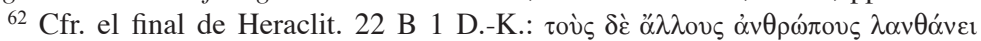

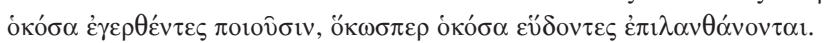

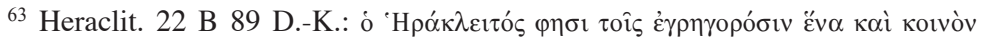

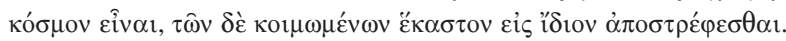

${ }^{64}$ Para el texto y la interpretación del fragmento, que difieren de lo que ofrecen Diels-Kranz y otros intérpretes, sigo la propuesta hecha por Gabor Betegh en su ponencia "Heraclitus 22 B 45: Its Text and Interpretation", presentada en el Secundum Symposium Heracliteum (UNAM, 23-26 de junio de 2006), que será incluida en las Actas correspondientes (actualmente en prensa). Para el alma cósmica en Heráclito se puede consultar también, del mismo autor, "Eschatology and Cosmology", en M. M. Sassi (ed.), La costruzione del discorso filosofico nell'età dei presocratici, Pisa, Edizioni della Normale, 2006. 
las más diferentes vías, ${ }^{65}$ declarara inalcanzables por vía experimental las fronteras del alma-cosmos, cuyo logos divino la volvería inaccesible para las limitadas capacidades humanas. Además, parece justificado poner en relación esta postura negativa hacia la posibilidad del saber humano con la perentoria exhortación del mismo Heráclito - contenida en el fragmento Heraclit. 22 B 50 D.-K., que citamos al inicio de este trabajo- a reconocer la unicidad de la sabiduría, para lo cual éste invoca expresamente la autoridad del $\lambda$ ó $\gamma$ os. Por otro lado, la concepción de que hay una fuente única del saber, idéntica al principio de organización que implanta el orden sobre la engañosa multiplicidad visible, con énfasis particular en la naturaleza eminentemente epistémica de dicho principio conductor, aparece claramente expresada en este pasaje:

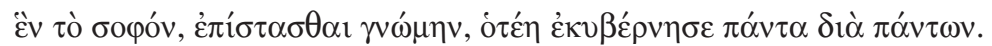
Una sola cosa es lo sabio, conocer el proyecto que gobierna todo por todos los medios.

(Heraclit. 22 B 41 D.-K.)

En la misma línea de pensamiento parece colocarse un frag-

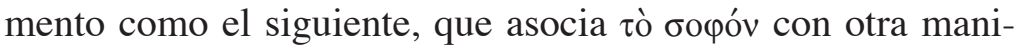
festación singular, que es homónima de la divinidad suprema que tiene en sus manos el control de todo:

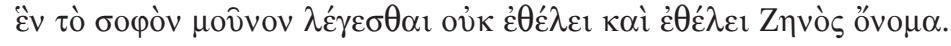

Una sola cosa, la única sabia, no quiere y sí quiere recibir el nombre de Zeus.

(Heraclit. 22 B 32 D.-K.)

Con su postura exclusivista acerca del principio epistémico se vincula también la descalificación, por parte de Heráclito, de

\footnotetext{
${ }^{65}$ En Heraclit. 22 B 40 D.-K. se fustiga a Hesíodo, Pitágoras, Jenófanes y Hecateo por su acumulación de conocimientos no basada en el reconocimiento

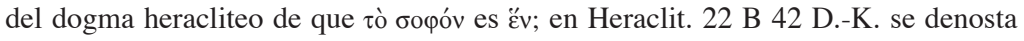
severamente a Homero y Arquíloco; en Heraclit. 22 B 56 y 105 D.-K. se ridiculiza la sabiduría de Homero y en Heraclit. 22 B 57 y 106 D.-K. la de Hesíodo.
} 
todos los intentos anteriores por captar el sentido de la sabiduría, de la que sólo él habría reconocido la posición especial:

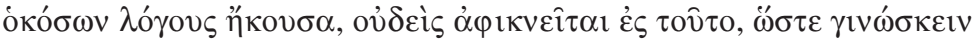

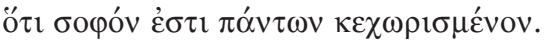

De cuantos escuché los discursos, ninguno llega al grado de reconocer que lo sabio es algo separado de todas las cosas.

(Heraclit. 22 B 108 D.-K.)

Por otro lado, frente a la afirmación categórica de la singulari-

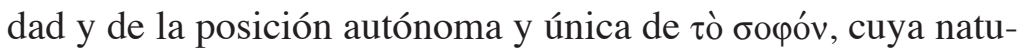
raleza divina y capacidad de control lo identifica como virtual

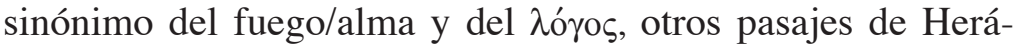
clito enfocan el problema del origen del pensamiento desde el punto de vista humano, sosteniendo que dicha facultad es común a todos los hombres:

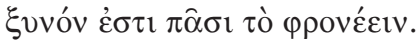

Es común para todos el pensar.

(Heraclit. 22 B 113 D.-K.)

$y$ en

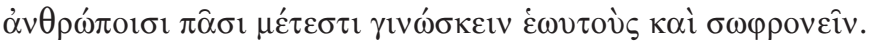

Todos los hombres participan del conocerse a sí mismos y del ser sensatos.

(Heraclit. 22 B 116 D.-K.)

La atribución en estas sentencias de un alcance universal a la

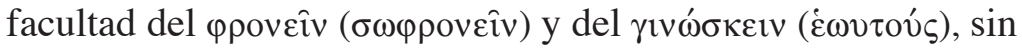
embargo, crea un aparente contraste con lo que el propio Heráclito afirmaba en algunos pasajes citados un poco antes, donde planteaba más bien una situación de absoluta inalcanzabilidad

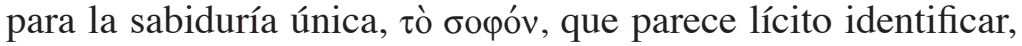
como vimos, con el principio inteligente que gobierna todo, el $\lambda$ ó $o$ s. La paradoja aparente que de ello resulta se desvanece, no obstante, en cuanto se toma en consideración una declaración del propio Heráclito, citada más arriba, según la cual 
"Aunque el logos sea común, la muchedumbre vive como si tuviera un pensamiento propio" (Heraclit. 22 B 2 D.-K.). En efecto, el logos, que en calidad de principio material se manifiesta como fuego, es también el alma universal o substrato común del que todo proviene y al que todo regresa, y además el mismo que, junto con la vida, otorga a cada uno, transitoriamente, la capacidad del pensamiento racional. La inteligencia individual, pues, como señalábamos antes, sería una suerte de préstamo temporal o participación pasajera en el logos cósmico, porque según Heráclito todas las cosas vuelven, una vez cumplido su ciclo vital, al punto de donde surgieron, a la fuente común de todo.

Así pues, creemos haber mostrado en estas páginas cómo en la doctrina de Heráclito, pese a su complejidad y aparente oscuridad de lenguaje, se desarrolla enormemente la concepción epistémica del alma, pues asistimos por primera vez a una diferenciación explícita, a nivel verbal, de las diferentes funciones que, según todas las doctrinas presocráticas arriba consideradas, están englobadas en ella. Por otro lado, es notable en Heráclito el énfasis especial en el logos, que redimensiona grandemente el enfoque antiguo hacia el alma como depositaria del conocimiento. Cabe señalar, no obstante, la persistencia en Heráclito de la indiferenciación entre material y espiritual - un rasgo común a todo el pensamiento presocrático, por cierto-, en virtud de la cual el substrato material de los seres les transmite igualmente el impulso vital y, en especial, la capacidad misma del discernimiento. Dicha postura teórica, que tiene sin duda resabios de misticismo arcaico, reaparece con diferentes matices en los sistemas elaborados por pensadores presocráticos contemporáneos y posteriores, incluso en los de aquellos que se propusieron construirlos sobre fundamentos más rigurosamente lógicos. A estos sistemas, sin embargo, cuyo número y complejidad es también considerable, dedicaremos una contribución sucesiva. 